\title{
Differentiation of Peanut Seedborne Potyviruses and Cucumoviruses by RT-PCR
}

Ralf G. Dietzgen, Queensland Government, Department of Primary Industries, Queensland Agricultural Biotechnology Centre, Gehrmann Laboratories, The University of Queensland, St. Lucia Qld 4072, Australia; Ben Callaghan, Queensland Government, Department of Primary Industries, Queensland Agricultural Biotechnology Centre, Gehrmann Laboratories, The University of Queensland, St. Lucia Qld 4072, Australia; and Botany Department, The University of Queensland, St. Lucia Qld 4072, Australia; Colleen M. Higgins, Queensland Government, Department of Primary Industries, Queensland Agricultural Biotechnology Centre, Gehrmann Laboratories, The University of Queensland, St. Lucia Qld 4072, Australia; Robert G. Birch, Botany Department, The University of Queensland, St. Lucia Qld 4072, Australia; Kunrong Chen and Zeyong Xu, Oil Crops Research Institute, Chinese Academy of Agricultural Sciences, 430062 Wuhan, China

\begin{abstract}
Dietzgen, R. G., Callaghan, B., Higgins, C. M., Birch, R. G., Chen, K., and Xu, Z. 2001. Differentiation of peanut seedborne potyviruses and cucumoviruses by RT-PCR. Plant Dis. 85:989992.

Seedborne peanut viruses pose important constraints to peanut production and safe movement of germ plasm. They also pose a risk of accidental introduction into previously disease-free regions. We have developed reverse transcription-polymerase chain reaction (RT-PCR) assays based on identical cycling parameters which identified peanut stripe, Peanut mottle, Peanut stunt, and Cucumber mosaic viruses through production of specific DNA fragments of $234 \mathrm{bp}$, $327 \mathrm{bp}, 390 \mathrm{bp}$, and $133 \mathrm{bp}$, respectively. Assay sensitivity in the picogram range was achieved. The two potyviruses and two cucumoviruses could be differentiated using duplex RT-PCR assays. These assays should be useful for testing peanut leaves or seeds for virus identification in epidemiological studies, seed testing or in post-entry quarantine.
\end{abstract}

Additional keywords: duplex RT-PCR, groundnut, virus diagnosis

Peanut (Arachis hypogaea L.) is one of the world's major oilseed crops and a staple food in many countries, including China, India, and Indonesia (16). More than 20 viruses have been found to infect this species naturally. Four of these viruses, peanut stripe virus (PStV), Peanut mottle virus (PeMoV), Cucumber mosaic virus (CMV), and Peanut stunt virus (PSV) are seedborne and transmitted by aphids in a nonpersistent manner. They are of particular economic importance in developing countries since they cause severe reductions in seed yield and quality $(1,13,22,23)$. PStV, a strain of Bean common mosaic virus (BCMV), and $\mathrm{PeMoV}$ are members of the genus Potyvirus (family Potyviridae), while CMV and PSV belong to the genus Cucumovirus (family Bromoviridae). Symptoms on peanut caused by these viruses vary depending on virus isolate, peanut cultivar and time of

Corresponding author: Ralf G. Dietzgen

E-mail: r.dietzgen@mailbox.uq.edu.au

Current address of Colleen Higgins: Genesis Research \& Development Corporation Ltd., P.O. Box 50, Auckland, New Zealand.

Accepted for publication 31 May 2001.

Publication no. D-2001-0717-04R

(C) 2001 The American Phytopathological Society infection, so that definite diagnosis based on symptoms alone is difficult $(1,10$, 18,23). The potyviruses PStV and PeMoV frequently induce similar symptoms, as do the cucumoviruses PSV and CMV. Serological methods such as enzyme-linked immunosorbent assay (ELISA) are commonly used for diagnosis of these viruses in peanut and other crops $(4,12,22)$. However, CMV and PSV show cross-reactivity and are difficult to distinguish serologically, especially in mixed infections in peanut plants in the field (24).

Sensitive diagnostic assays are essential tools for early detection of virus-infected plants, epidemiological studies, implementation of control measures, provision of virus-free planting material, international exchange of germ plasm and quarantine protection. Virus diagnosis to species level is important because disease management strategies may vary considerably, depending on the virus. In the United States, there is currently an effort to detect all seedborne viruses in newly introduced peanuts and to eliminate these viruses from planting material (6). The polymerase chain reaction (PCR) is a powerful, sensitive, and versatile technique, which is increasingly being used for plant virus detection and differentiation (5). Despite extensive biological diversity, genetic variability of PStV isolates in the coat protein gene is limited to $3.5 \%$ within and $7.3 \%$ between geographic groups (10). This provides a good basis for nucleic acid-based diagnosis of a wide range of isolates. The aim of this study was to develop sensitive reverse transcriptionpolymerase chain reaction (RT-PCR) assays to detect and differentiate four seedborne viruses of peanut. The potential for multiplexing these assays using identical amplification parameters was also investigated.

\section{MATERIALS AND METHODS}

Viruses and sample preparation. The Indonesian "blotch" (Ib) isolate of PStV (20) was maintained in peanut cv. Gajah. Putative PStV-infected peanut leaf samples were collected in Indonesia as part of a Northern Australia Quarantine Strategy survey and stored dried over $\mathrm{CaCl}$. PeMoV isolate 133E (20) was maintained in bean (Phaseolus vulgaris) cv. Bountiful. Both potyviruses were purified as described by Hammond and Lawson (7). Australian CMV isolates 238 (subgroup I) and 241 (subgroup II) were maintained in cucumber (Cucumis sativus), and an isolate from gladiolus (CMV-G) was purified as described by Palukaitis et al. (14). Chinese PSV isolates mild (Mi) and severe (S) were purified and viral RNA extracted as described by $\mathrm{Xu}$ et al. (23). Viral RNA was released from small pieces of infected leaf by boiling for $10 \mathrm{~min}$ in template preparation solution (TPS; $100 \mathrm{mM}$ Tris- $\mathrm{HCl}, \mathrm{pH}$ 7.4, $1 \mathrm{M} \mathrm{KCl}, 10 \mathrm{mM}$ EDTA) as described by Thomson and Dietzgen (21) and stored at $-70^{\circ} \mathrm{C}$. Aliquots of such "leaf soak" preparations were diluted $1 / 10$ in sterile distilled water just prior to use as template in RT-PCR.

Primers. Specific oligonucleotide primers were designed and assessed for the detection and differentiation by RT-PCR of the seedborne peanut viruses PStV, PeMoV, PSV, and CMV in peanut leaf tissues. The primers were designed to bind to nucleotide sequences in or flanking the coat protein genes of these four viruses (Table 1) and to possess compatible annealing temperatures for development of multiplex assays. Several primer pairs were designed for each virus, using Oligo 4.0 (Molecular Biology Insights, Cascade, 
CO). Primers were synthesized by Genset Pacific (Lismore, Australia). PCR annealing temperatures were optimized using a model PC-960 thermal cycler, (Corbett Research, Sydney, Australia) which was set to provide a temperature-gradient in $\sim 1^{\circ} \mathrm{C}$ steps across the heating block.

RT-PCR. Components of the Superscript One-Step RT-PCR System (Invitrogen Life Technologies, Melbourne, Australia) in $25 \mu \mathrm{l}$ reactions were used in the assays shown. Initial assays and those done in China used the Access RT-PCR kit (Promega, Madison, WI). Potyvirus duplex reaction mix contained $0.4 \mu \mathrm{M}$ of each primer PST1, PST2, PeMo14, and PeMo17. CMV was detected using $0.4 \mu \mathrm{M}$ of each primer $\mathrm{CMV}^{\prime}$ and CMV5'. $\mathrm{Cu}-$ cumovirus duplex reaction mix contained $0.4 \mu \mathrm{M}$ of each primer CMV5', CMV-B, PSV2, and PSV5. Model 480 or 9700 thermal cyclers (Perkin Elmer Applied Biosystems, Foster City, CA) were used with the following cycling parameters: $72^{\circ} \mathrm{C}$ for $5 \mathrm{~min}, 48^{\circ} \mathrm{C}$ for $45 \mathrm{~min}, 94^{\circ} \mathrm{C}$ for $2 \mathrm{~min},\left(40\right.$ cycles of $94^{\circ} \mathrm{C}$ for $45 \mathrm{~s}, 54^{\circ} \mathrm{C}$ for $45 \mathrm{~s}, 72^{\circ} \mathrm{C}$ for $1 \mathrm{~min}$ ), and 1 cycle of $72^{\circ} \mathrm{C}$ for $10 \mathrm{~min}$. In China, RT-PCR was done in a Model 2400 (Perkin Elmer Applied Biosystems, Foster City, CA) thermal cycler using the following parameters: $48^{\circ} \mathrm{C}$ for $60 \mathrm{~min}, 94^{\circ} \mathrm{C}$ for $2 \mathrm{~min},\left(40\right.$ cycles of $94^{\circ} \mathrm{C}$ for $30 \mathrm{~s}, 50^{\circ} \mathrm{C}$ for $1 \mathrm{~min}, 68^{\circ} \mathrm{C}$ for $2 \mathrm{~min}$ ), and 1 cycle of $68^{\circ} \mathrm{C}$ for $7 \mathrm{~min}$. PCR products were assessed by electrophoresis in 1 to $1.2 \%$ agarose gels in TBE buffer (89 mM Tris-borate and 2 mM EDTA, $\mathrm{pH} 8.3$ ), stained with ethidium bromide and viewed under ultraviolet light.

\section{RESULTS}

Cloned cDNA templates containing the target sequences were used initially to assess the primer sets by temperaturegradient PCR $\left(53\right.$ to $\left.60^{\circ} \mathrm{C}\right)$, to ensure they yielded a single virus-specific PCR product of expected size (data not shown). All primers performed well at an annealing temperature of $54^{\circ} \mathrm{C}\left(50^{\circ} \mathrm{C}\right.$ in China).

PST primers 1 and 2 only yielded a RTPCR product for PStV, but not for PeMoV, PSV or CMV. PStV could be detected in infected peanut leaf when TPS extracts were diluted $1 / 20$ to $1 / 320$, and in infected peanut seed extracts diluted $1 / 10$ to $1 / 20$ (data not shown). A broad range of bio- logically diverse PStV isolates from China, Indonesia, Thailand, and the United States have been detected by RT-PCR using this primer set $(1,8,10$; data not shown). PST primers 1 and 2 also amplified a fragment of the same size (234 bp) from beaninfecting strains of BCMV (data not shown). Primers PST 1 and 2 may well be specific for BCMV strains in general, but this has not been investigated. PeMo14 and PeMo17 primers were specific for $\mathrm{PeMoV}$ template, because they yielded only an RTPCR product of the expected size from PeMoV-infected samples, but not from PStV, PSV, or CMV.

In a duplex RT-PCR, primers PeMo14 and PeMo17 yielded a 327 bp product from a preparation of purified PeMoV (Fig. 1, lane 1), while PST1 and PST2 yielded the expected 234 bp product from a purified preparation of PStV-Ib (Fig. 1, lane 2). When both viral templates were added together, the two viruses could clearly be differentiated from the unique size of their PCR products (Fig. 1, lane 3). No interference between the four primers and their two templates was apparent. Both potyviruses were also clearly distinguished in diluted "leaf soak extracts" from PStVinfected peanut (Fig. 1, lanes 5 and 6) or PeMoV-infected bean (Fig. 1, lanes 7 and 8). No PCR products were visible in extracts from uninfected peanut leaves or when no template was added (Fig. 1, lanes 4 and 12 , respectively). PStV was also identified in desiccated peanut leaf samples collected in Indonesia. Representative examples of two PStV-positive and one negative specimen are shown in Figure 1 (lanes 9 to 11).

CMV primers $3^{\prime}$ and $5^{\prime}$, which had previously been used in multiplex RT-PCR for seedborne legume viruses (2) and viruses infecting banana (19), yielded a single product of about $500 \mathrm{bp}$ for isolates of CMV subgroups I and II in uniplex RTPCR. Subgroup I isolates yielded a product larger by about 15 bp compared to subgroup II isolates (data not shown). Ten picograms of purified CMV could be detected reproducibly in a stained gel, $1 \mathrm{pg}$ was sometimes visible as a faint band (Fig. 2A, lanes 2 to 5). However, in initial PCR experiments using cloned cDNA templates primers CMV3' and CMV5' were not specific for CMV, because they also yielded a 700 bp product for PSV (data not shown). Furthermore, in cucumovirus duplex RT$\mathrm{PCR}$, primer $\mathrm{CMV}^{\prime}$ appeared to contribute to the appearance of spurious bands, since its replacement by primer CMV-B eliminated the problem (Fig. 2B). The new primer combination $\mathrm{CMV5}^{\prime}$ and $\mathrm{CMV}-\mathrm{B}$ appeared to be specific for CMV since it did not yield a product with TPS extracts from peanut leaves infected with PSV in China (data not shown).

Primer pair PSV2 and PSV5 appeared to be specific for PSV because it did not yield a PCR product from CMV subgroup I or II isolated from cucumber or from CMVinfected peanut leaf extracts in China (data not shown). In a duplex RT-PCR containing PSV- and CMV-specific primer sets

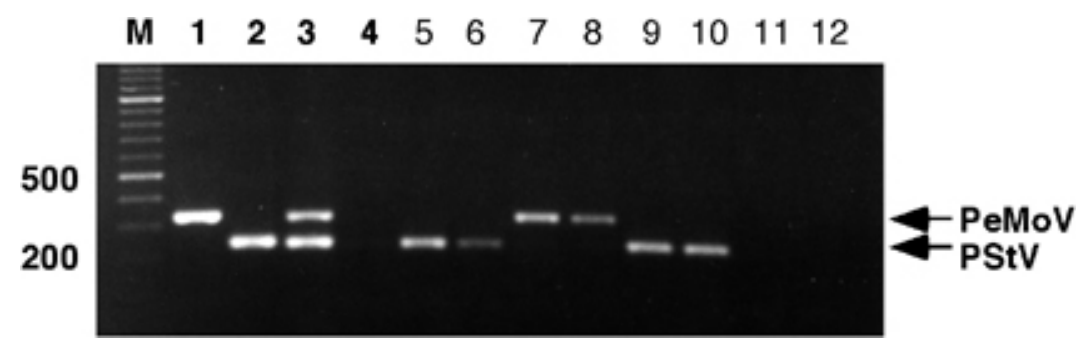

Fig. 1. Potyvirus duplex reverse transcription-polymerase chain reaction (RT-PCR) detecting peanut stripe (PStV) and peanut mottle (PeMoV) viruses in 1\% agarose gel. Lane M contains a 100-basepair DNA ladder marker; lanes 1 to 3 contain purified virus; lanes 4 to 11 contain leaf extracts, and lane 12 is a no-template control; lane $1=\mathrm{PeMoV}$; lane $2=\mathrm{PStV}$; lane $3=\mathrm{PeMoV}+\mathrm{PStV}$; lane $4=$ uninfected peanut extract $1 / 20$; lanes 5, $6=\mathrm{PStV}$-infected peanut $1 / 20,1 / 100$; lanes 7, $8=\mathrm{PeMoV}$ infected bean $1 / 20,1 / 80$; lanes 9 to $11=$ field-collected peanut samples of unknown disease status 1/20. Selected DNA size markers and DNA bands indicative of PStV or PeMoV are indicated in the margins.

Table 1. Primer pairs used for detection of specific peanut viruses in reverse transcription-polymerase chain reaction (RT-PCR)

\begin{tabular}{|c|c|c|c|c|c|c|}
\hline Virus & Primer & Sequence $5^{\prime} \rightarrow \mathbf{3}^{\prime}$ & Polarity & Target sequence & Fragment (bp) & Reference \\
\hline \multirow{2}{*}{ PStV } & PST 1 & GCATGCCCTCGCCATTGCAA & Antisense & $3^{\prime} \mathrm{UTR}^{\mathrm{a}}$ & & 11 \\
\hline & PST 2 & GCACACACTTCTTGGCATGG & Sense & $\mathrm{CP}$ & 234 & 11 \\
\hline \multirow[t]{2}{*}{ PeMoV } & PeMo 14 & GCTGTGAATTGTTGTTGAGAA & Antisense & $\mathrm{CP}$ & & This paper \\
\hline & PeMo 17 & ACAATGATGAAGTTCGTTAC & Sense & $\mathrm{NIb}$ & 327 & This paper \\
\hline \multirow[t]{3}{*}{ CMV } & CMV 5' & TATGATAAGAAGCTTGTTTCGCGCA & Sense & $\mathrm{CP}$ & & 2 \\
\hline & CMV $3^{\prime}$ & TTTTAGCCGTAAGCTGGATGGACAACCC & Antisense & $\mathrm{CP}$ & $\sim 500$ & 2 \\
\hline & CMV B & ACATAGCAGAGATGGCGGC(AG)ACGGA & Antisense & $\mathrm{CP}$ & 133 & This paper \\
\hline \multirow[t]{2}{*}{ PSV } & PSV 2 & CGATATACCTTTTGGGTTCA & Sense & IG & & This paper \\
\hline & PSV 5 & CCGAAACTTTGACCCTTCTCAG & Antisense & $\mathrm{CP}$ & 390 & This paper \\
\hline
\end{tabular}

a $3^{\prime} \mathrm{UTR}=3^{\prime}$ untranslated region; $\mathrm{CP}=$ coat protein gene; $\mathrm{NIb}=$ polymerase gene; $\mathrm{IG}=$ intergenic region 
and both viral templates, the PSV primers yielded a single product of $390 \mathrm{bp}$ from 10 pg of purified PSV template diluted in "leaf soak extract" from uninfected peanut (Fig. 2B, lanes 1 to 3 ). CMV primers $5^{\prime}$ and $\mathrm{B}$ yielded a $133 \mathrm{bp}$ product. Sensitivity was about tenfold less than with the CMV primers $5^{\prime}$ and $3^{\prime}$ in a uniplex PCR (compare Fig. 2A and B). A small product of less than $50 \mathrm{bp}$ in all reactions, including the no template control (Fig. 2B, lanes 1 to 4 ), is assumed to comprise primer dimers.

\section{DISCUSSION}

We have developed RT-PCR assays for the detection of four economically important seedborne peanut viruses. These onetube assays use the same reverse transcription and amplification conditions, and yield characteristically sized products for each of the viruses. Duplex RT-PCR for the two potyviruses PStV and PeMoV and the two cucumoviruses CMV and PSV were developed, but additional multiplexing proved unsuccessful, probably due to unexpected interactions between potyvirus and cucumovirus primer and template sequences similar to those described by Sharman et al. (19).

A spectrum of closely related, but biologically varied PStV isolates exists in all geographic regions where this virus is endemic, and the $\mathrm{CP}$ gene does not appear to be a significant symptom determinant $(9,10)$. RT-PCR assays using primers targeting nucleotide polymorphisms in the $\mathrm{CP}$ gene have previously been used to differentiate biological strains of PStV (15). Using the primers PST1 and PST2, we and others have been able to detect a broad range of PStV isolates from China, Indonesia, the United States, and Thailand $(1,8,9,10)$. PCR using these primers has also been used to identify transgenic peanut leaf and embryo tissues carrying the PStV coat protein gene (11).

Contrary to the observations of Gillaspie et al. (6), the combination of our two sets of primers for the differentiation of PStV and $\mathrm{PeMoV}$ did not produce spurious bands (Fig. 1). The duplex RT-PCR of the two seedborne potyviruses was reliable, and it is being used for surveys of peanut viruses in China and for testing of quarantine material in Australia.

Recently, an immunocapture RT-PCR assay was developed for testing of peanut seed lots for infection by PStV and PeMoV. RT-PCR was more sensitive than ELISA and results of both assays showed a good correlation (6). Inclusion of an immunocapture step in the duplex RT-PCR assays reported here may overcome inhibitors of PCR present in peanut seed extracts (5), and make RT-PCR useful for large scale nondestructive testing of peanut germ plasm for seedborne viruses. Use of internal hybridization probes for colorimetric or fluorescent detection of PCR products $(17,19)$ will add a second level of specific- ity to the diagnostic assays and eliminate any problem of nonspecific bands in multiplex PCR. Furthermore, real-time PCR provides increased sensitivity and the potential for virus quantification $(5,17)$.

Many diagnostic assays including RTPCR (e.g., 2,12) have been developed for CMV. Recently, RT-PCR using a pair of cucumovirus genus-specific primers detected CMV, PSV, and Tomato aspermy virus, which could be differentiated by subsequent restriction fragment length polymorphism (3). Furthermore, immunocapture multiplex (RT)-PCR was recently developed for the detection of three banana viruses (19) one of which was CMV. For the first time, our RT-PCR assays for CMV and PSV provide a means to differentiate directly between these two cucumoviruses. Careful selection of PCR primers was essential to avoid detrimental interactions between heterologous templates and primers in the cucumovirus duplex RT-PCR. Except for the PStV assay, our RT-PCR assays were assessed only with a small number of isolates, and it will be important to confirm their robustness with a more extensive collection of isolates.

A

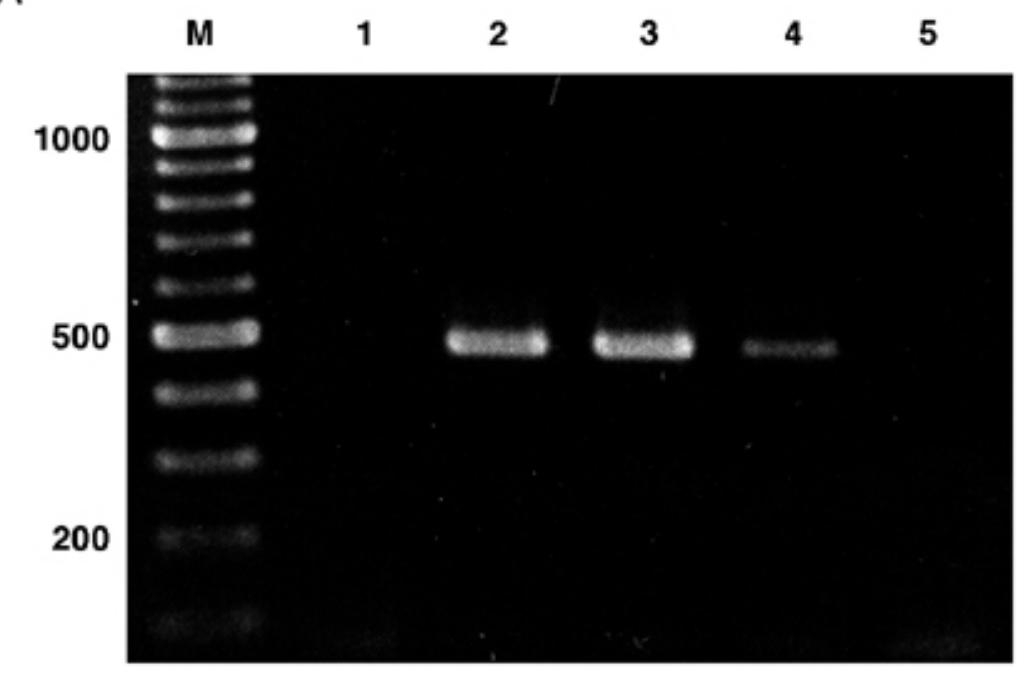

B 1 2 3 4

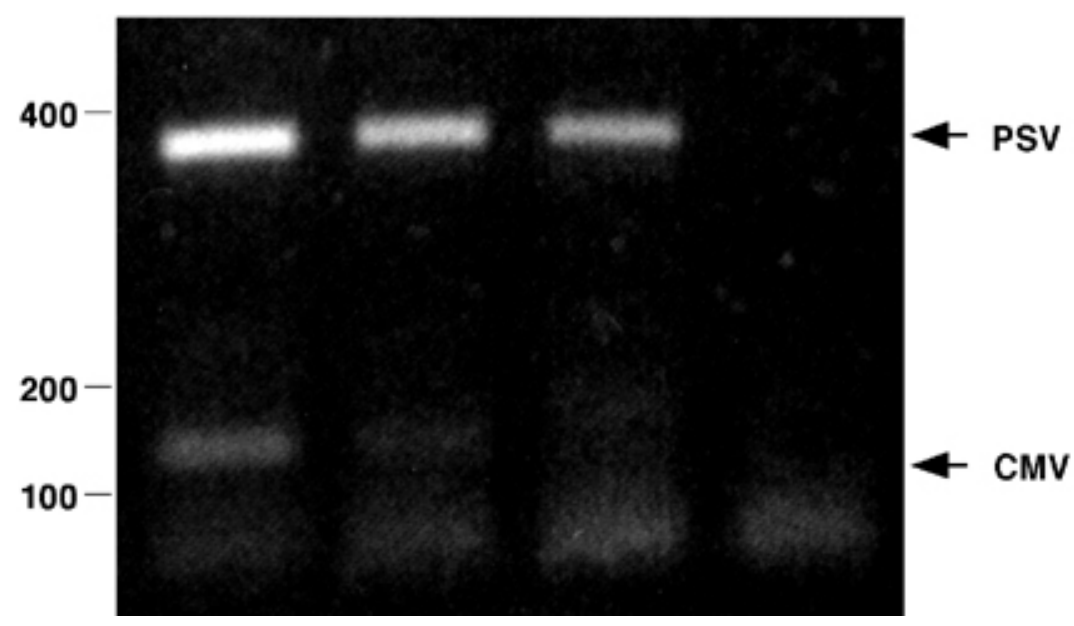

Fig. 2. A, Detection of Cucumber mosaic virus (CMV) using primers CMV5' and CMV3' and analysis of polymerase chain reaction (PCR) products in 1.2\% agarose gel. Lane M contains a $100 \mathrm{bp}$ DNA ladder marker; lane 1 is a no-template control; lanes 2 to 5 contain purified CMV-G, 1000, 100, $10,1 \mathrm{pg}$. B, Cucumovirus duplex reverse transcription-polymerase chain reaction (RT-PCR) differentiating cucumber mosaic (CMV) and peanut stunt (PSV) viruses in 1.2\% agarose gel. Lanes 1 to 3 contain a 10-fold dilution series starting with a cocktail containing $1 \mathrm{ng}$ each of purified CMV-G and PSV-S in 1/10 diluted extract of uninfected peanut leaf; lane $4=1 / 100$ diluted extract of uninfected peanut leaf. Samples were amplified using primers CMV5', CMV-B and PSV2, PSV5. Selected DNA size markers and DNA bands indicative of PSV- and CMV-specific PCR products are indicated in the margins. 


\section{ACKNOWLEDGMENTS}

This study was supported by the Australian Centre for International Agricultural Research (ACIAR PN 9439). We thank John E. Thomas for PeMoV and CMV isolates and for helpful discussions and Richard Davis, and AQIS for field samples collected in Indonesia. Work with PStV and PSV was conducted under permits from the Australian Quarantine and Inspection Service (AQIS).

\section{LITERATURE CITED}

1. Akin, H. M., and Sudarsono. 1997. Characterization of peanut stripe virus (PStV) isolates originated from various provinces in Indonesia. Indon. J. Trop. Agric. 8:13-20.

2. Bariana, H. S., Shannon, A. L., Chu, P. W. G., and Waterhouse, P. M. 1994. Detection of five seedborne legume viruses in one sensitive multiplex polymerase chain reaction test. Phytopathology 84:1201-1205.

3. Choi, S. K., Choi, J. K., Park, W. M., and Ryu, K. H. 1999. RT-PCR detection and identification of three species of cucumoviruses with a genus-specific single pair of primers. J. Virol. Methods 83:67-73.

4. Demski, J. W., and Warwick, D. 1986. Testing peanut seeds for peanut stripe virus. Peanut Sci. 13:38-40

5. Dietzgen, R. G. 2001. Application of PCR in Plant Virology. Chapter 21 in: Plant Viruses as Molecular Pathogens. J. A. Khan and J. Dijkstra, eds. Haworth Press Inc., New York. In press.

6. Gillaspie, A. G., Jr., Pittman, R. N., Pinnow, D. L., and Cassidy, B. G. 2000. Sensitive method for testing seed lots for Peanut stripe and Peanut mottle viruses by immunocapturereverse transcription-polymerase chain reaction. Plant Dis. 84:559-561.
7. Hammond, J. L., and Lawson, R. H. 1988. An improved procedure for preparing potyviruses and cytoplasmic inclusions from the same tissue. J. Virol. Methods 20:203-217.

8. Higgins, C. M., Cassidy, B. G., Teycheney, P.Y., Wongkaew, S. and Dietzgen, R. G. 1998. Sequences of the coat protein gene of five peanut stripe virus (PStV) strains from Thailand and their evolutionary relationship with other bean common mosaic virus sequences. Arch. Virol. 143:1655-1667.

9. Higgins, C. M., Cook, G., Pietersen, G., and Dietzgen, R. G. 1999. Molecular characterisation of a strain of peanut stripe virus from peanut germplasm imported into South Africa. Afr. Plant Prot. 5:5-12.

10. Higgins, C.M., Dietzgen, R. G., Akin, H. M., Sudarsono, Chen, K., and Xu, Z. 1999. Biological and molecular variability of peanut stripe potyvirus. Curr. Topics Virol. 1:1-26.

11. Higgins, C. M., Hall, R. M., Campbell, P. R., and Dietzgen, R. G. 2000. PCR rescue and analysis of transgene sequences directly from crude extracts of transgenic embryos and plants. Plant Mol. Biol. Rep.18:285.

12. Hu, J. S., Li, H. P., Barry, K., Wang, M., and Jordan, R.1995. Comparison of dot blot, ELISA, and RT-PCR assays for detection of two cucumber mosaic virus isolates infecting banana in Hawaii. Plant Dis. 79:902-906.

13. Kuhn, C. W. 1965. Symptomatology, host range, and effect on yield of a seedtransmitted peanut virus. Phytopathology 55:880-884.

14. Palukaitis, P., Roossinck, M. F., Dietzgen, R. G., and Francki, R. I. B. 1992. Cucumber mosaic virus. Adv. Virus Res. 41:281-348.

15. Pappu, S. S., Pappu, H. R., Chang, C. A., Culbreath, A. K., and Todd, J. W. 1998. Differentiation of biologically distinct peanut stripe potyvirus strains by nucleotide polymorphism-based assay. Plant Dis. 82:1121 1125.

16. Reddy, D. V. R. 1991. Groundnut viruses and virus diseases: Distribution, identification and control. Rev. Plant Pathol. 70:665-678.

17. Roberts, C. A., Dietzgen, R. G., Heelan, L. A., and Maclean, D. J. 2000. Real time RT-PCR fluorescent detection of Tomato spotted wilt virus. J. Virol. Methods 88:1-8.

18. Saleh, N., Horn, N. M., Reddy, D. V. R., and Middleton, K. J. 1989. Peanut stripe virus in Indonesia. Neth. J. Plant Path. 95:123-127.

19. Sharman, M., Thomas, J. E., and Dietzgen, R. G. 2000. Development of a multiplex immunocapture PCR with colourimetric detection for viruses of banana. J. Virol. Methods 89:75-88.

20. Teycheney, P.-Y.,and Dietzgen, R. G.1994 Cloning and sequence analysis of the $\mathrm{CP}$ gene of an Australian strain of peanut mottle and an Indonesian 'blotch' strain of peanut stripe potyviruses. Virus Res. 31:235-244.

21. Thomson, D., and Dietzgen, R. G.1995. Detection of DNA and RNA plant viruses by PCR and RT-PCR using a rapid virus release protocol without tissue homogenization. J. Virol. Methods 54:85-95.

22. Xu, Z., Chen, K., Zhang, Z., Chen, J. 1991. Seed transmission of peanut stripe virus in peanut. Plant Dis. 75:723-726.

23. Xu, Z., Higgins, C. M., Chen, K., Dietzgen, R. G., Zhang, Z., Yang, L. and Fang, X. 1998. Evidence for a third taxonomic subgroup of peanut stunt virus from China. Plant Dis. 82:992-998.

24. Xu, Z., and Zhang, Z. 1988. Occurrence and distribution of peanut virus diseases and serological diagnosis of the viruses in China. Oil Crops China 2:56-61. 